\title{
Türk Turizm Sektörünün Finansal Performansının Dikey Analiz Yöntemiyle İncelenmesi: BiST Turizm Şirketleri ve TCMB Sektör Bilançoları Üzerinde Bir Araştırma
}

Erdinç KARADENIZ, Department of Tourism Management, Faculty of Tourism, Mersin University, Turkey; email: ekaradeniz@mersin.edu.tr

Mehmet BEYAZGÜL, Department of Tourism Management, Faculty of Tourism, Mersin University, Turkey; email: m.beyazgul1553@mersin.edu.tr

Selda DALAK, Department of Tourism Management, Faculty of Tourism, Mersin University, Turkey; e-mail: seldakhl@mersin.edu.tr

Fatih G̈̈UAY, Department of Tourism Management, Faculty of Tourism, Mersin University, Turkey; e-mail: fgunay@mersin.edu.tr

\section{Investigation of Turkish Tourism Sectors' Financial Performance by Vertical Analysis Method: A Research on BIST Tourism Companies and CBRT Company Accounts}

\begin{abstract}
The main purpose of this study is to analyze and exhibit the financial performance of tourism companies which publicly traded in Borsa İstanbul (BIST) and to make comparison with tourism company accounts by using vertical analysis method. In this study, it is examined that the financial statements of publicly traded tourism companies in Borsa İstanbul and Central Bank of the Republic of Turkey (CBRT) Accommodation and Food Service Subsector company accounts for 2014 by using vertical analysis method. As a result of analysis, it is determined that BIST tourism companies have more property, plant and equipment than accommodation and food service subsector. In addition, it is determined that tourism companies use mainly equity by financing their property plant and equipment. In the context of income statement, it is specified that tourism companies and subsector have almost same percentage of cost of sales and administrative expenses. Except that, while period profit of subsector \%5, three of BIST tourism companies make loss. Besides that other seven tourism company have highly profit margin than accommodation and food service subsector. In this context, it is found that non-operating income or loses have more portion than sales in publicly traded tourism companies by generate profit or loses.
\end{abstract}

\section{Keywords}

JEL Classification Codes :

\section{Accommodation and Food Service Subsector.}

L83, Z31, Z33.

\section{Öz}

Bu çalışmanın temel amacı, hisseleri Borsa İstanbul'da işlem gören turizm şirketlerinin dikey analiz yöntemi ile finansal performanslarını ortaya koymak ve turizm sektörü ile bir karşılaştırma 
yapmaktır. Çalışmada, hisseleri Borsa İstanbul'da (BIST) işlem gören turizm şirketlerinin 2014 yılına ait finansal tabloları ve Türkiye Cumhuriyet Merkez Bankası (TCMB)'nın yayımladığı konaklama ve yiyecek hizmeti faaliyetleri alt sektörünün 2014 yılına ait finansal tabloları dikey analiz yöntemiyle incelenmiştir. Yapılan analiz sonucunda halka açık turizm şirketlerinin sektörün geneline göre daha yüksek oranda maddi duran varlığa sahip olduğu saptanmıştır. Ayrıca turizm şirketlerinin maddi duran varlıklarını özkaynaklarla finanse ettiği belirlenmiştir. Gelir tablosuna bakıldığında ise halka açık turizm şirketlerinin genel olarak sektörle benzer yüzdelerde satışların maliyeti ve genel yönetim giderlerine sahip oldukları görülmüştür. Ancak sektörün \%5 civarında bir dönem kârına sahip olduğu gözlemlenirken BİST turizm şirketlerinin üç tanesinin zarar ettiği, diğerlerinin ise sektöre göre çok daha yüksek kâr oranına sahip oldukları saptanmıştır. Buna göre halka açık turizm şirketlerinin dönem kârı ya da zararının oluşmasında satışlardan çok faaliyet dışı gelir ve giderlerinin payının olduğu sonucuna varılmıştır.

Anahtar Sözcükler $\quad$ : Dikey Analiz Yöntemi, Borsa İstanbul Turizm Şirketleri, Konaklama ve Yiyecek Hizmeti Faaliyetleri Alt Sektörü.

\section{Giriş}

Son zamanlarda dünyada yaşanan finansal krizler, işletmelerin planlama ve denetim unsurlarına daha fazla önem vermesi gerekliliğini ortaya çıkarmıştır. İşletmelerin planlama ve denetim işlevlerinin yerine getirilmesi ve sağlıklı yönetimsel kararlar alabilmesi açısından finansal analiz büyük öneme sahiptir. Türkiye gibi gelişmekte olan ülke ekonomilerinde turizm sektörünün gelir yaratmak konusunda gayri safi milli hâsıla içerisinde önemli bir payı olduğu bilinmektedir. Turizm işletmeleri, talebin sürekli değiştiği buna karşın sabit sermaye yatırımlarının genel olarak yüksek gerçekleştiği, risk ve belirsizliğin her zaman mevcut olduğu, operasyonel maliyetlerin kontrolünün her geçen gün zorlaştığı, kâr marjlarının düşük olduğu ve döviz kuru riskinin yüksek olduğu bir sektörde faaliyet göstermektedirler. Turizm işletmelerinin sabit sermaye yatırımlarının yüksek olması, devlet teşviklerinin son yıllarda azalması, uzun dönemli fon bulma konusundaki sorunlarla birlikte son yıllarda yaşanan finansal krizler ve 2016 y1lında Rusya ile yaşanan siyasi kriz turizm işletmelerinin finansal yapılarına daha fazla önem vermelerini gerekli hale getirmiştir. Tüm bunlar göz önüne alındığında turizm işletmelerinin finansal analiz tekniklerinden faydalanarak mevcut durumlarını kontrol altında tutmaları ve sektördeki diğer işletmeler ile finansal tablolarını karşılaştırarak durum tespiti yapmaları için finansal analizlerden faydalanmaları kaçınılmaz olmaktadır. Bu bağlamda çalışmanın amacı hisseleri Borsa İstanbul'da işlem gören turizm şirketlerinin dikey analiz yöntemi ile finansal durumlarının ortaya konması ve turizm sektörü ile karşılaştırılmasıdır. Çalışmanın alt amaçları, Borsa İstanbul turizm şirketlerinin 2014 yılına ait finansal durum tabloları ve kâr/zarar tablolarının dikey analizi yapılarak, söz konusu şirketlerin varlık, kaynak, gelir yaratma, maliyet ve gider politikalarının ortaya konması olarak belirlenmiştir. Aynı zamanda bu şirketler ile Türkiye Cumhuriyet Merkez Bankası (TCMB) sektör bilançolarında yer alan Konaklama ve Yiyecek Hizmeti Faaliyetleri Alt Sektörü'nün 2014 yılına ait finansal tabloları kıyaslanarak sorunlarının saptanması, şirketlere ve sektöre yönelik öneriler geliştirilmesi ve alan yazına katkı yapılması düşünülmektedir. Bu bağlamda çalışma beş bölümden oluşmaktadır. İkinci bölümde konuyla ilgili daha önce yapılmış 
çalışmaların yer aldığı literatür taraması yer almaktadır. Çalışmanın üçüncü bölümünde yöntem, dördüncü bölümde ise analiz ve bulgulara yer verilmektedir. Son olarak sonuç bölümünde genel bir değerlendirme yapılarak öneriler sunulmaya çalışılmıştır.

\section{Literatür}

Konuyla ilgili yapılan çalışmalara bakıldığında finansal analiz tekniklerinden dikey yüzde yönteminin kullanıldığı çalışmaların sayısının az olduğu, bununla birlikte çok sayıda oran analizi yönteminin kullanıldığı çalışmanın olduğu gözlemlenmiştir.

Dikey analiz yönteminin kullanıldığı çalı̧̧alara bakıldığında genelde, finansal tablolarında yer alan çeşitli hesap gruplarının birbirleriyle ve aynı zamanda diğer işletmelerdeki hesap gruplarıyla kıyaslanarak işletmelerin finansal performanslarının ve sıkıntılarının ortaya konulması amaçlandığı görülmektedir.

Gürkan (2009), basın işletmelerinin finansal yapılarının nasıl oluştuğunu incelemiş ve basın işletmelerinin finansal ihtiyaçlarını nasıl karşıladıklarını ortaya koymak amacıyla dikey analiz ve oran analizi tekniklerini kullanmıştır. Çalışmada Türkiye'de faaliyet gösteren iki büyük basın işletmesinin 2007, 2008 ve 2009 y1llarına ait finansal tabloları kullanılarak dikey analiz ve oran analizi gerçekleştirildiği görülmektedir. Çalışma sonucunda incelenen basın işletmelerinin duran varlık ağırlıklı oldukları ve bu varlıklarını büyük oranda özsermaye ile karşıladıkları diğer yandan satışların maliyetinin \%60 seviyelerinde gerçekleşirken gelirlerinin büyük bir bölümünün reklam ve ilan gelirlerinden oluştuğu ortaya çıkmıştır. Çalışmada basın işletmelerinin mali gücünün düşük olmasının sektörde tekelleşmeyi ve tarafsızlığın tam olarak sağlanamamasına yol açtığı belirtilmektedir.

Sevim, Bozdoğan ve Canbolat (2009), yaptıkları çalışmada kredi kurumları için bir kredi değerlendirme modeli geliştirmişlerdir. Çalışmada, bankaların ve kredi kurumlarının genelde işletmelerin kredi değerlerini paket programlar aracılığ 1 ile hesapladıkları ancak bu paket programların özellikle oran analizlerini kullanarak kredi çözümleri ürettikleri belirtilmektedir. Bunun üzerine çalışmada finansal tablolar analiz tekniklerinin birlikte kullanılmasının daha etkin sonuçlar vereceği düşünülerek yeni bir model önerilmiştir. Çalışmada finansal tablolar analiz tekniklerinin her biri ile analizler gerçekleştirilerek bu analizlerin sonuçlarına göre işletmelere her bir analiz türünden -1 ile 3 arasında puan verileceği ve bu puanlama neticesinde daha sağlıklı bir kredi notunun ortaya çıkarılabileceği anlatılmıştır.

Özyürek ve Erdoğan (2011), İMKB'de işlem gören bir finansal şirketin 2009-2010 yıllarına ait finansal analizini gerçekleştirmişlerdir. Çalışmanın bulguları incelendiğinde şirketin pasif kısmında mevduat kaleminin 2009 ve 2010 yıllarında sirasıyla $\% 64$ ve $\% 69$ civarında olduğu ve bununla birlikte krediler kaleminin de buna paralellik gösterdiği görülmektedir. Buna göre şirketin giderek güçlü bir mali yapıya ulaştığı ve büyüdüğü söylenmektedir. 
Karadeniz, E. \& M. Beyazgül \& S. Dalak \& F. Günay (2017), “Türk Turizm Sektörünün Finansal Performansının Dikey Analiz Yöntemiyle İncelenmesi: BİST Turizm Şirketleri ve TCMB Sektör Bilançoları Üzerinde Bir Araştırma”, Sosyoekonomi, Vol. 25(32), 105-119.

Bardia (2012), Hindistan'da faaliyet gösteren en büyük iki çelik imalatı şirketinin finansal sıkıntı ve uzun dönemli ödeme gücünün ortaya konulması amacıyla bir çalışma yapmıştır. Çalışmada 1997-2009 yılları arasındaki finansal tabloları kullanılan şirketlerden biri kamu sektörünün lider çelik imalat şirketi iken diğeri özel sektördeki en büyük çelik imalat şirketidir. Şirketlerin finansal sıkıntı durumlarının ortaya konulması amacıyla Altman'ın Z skoru modeli kullanılırken uzun dönemli ödeme gücünün ortaya konulması amacıyla dikey analiz yöntemi kullanılmıştır. Ayrıca oran analizi yöntemi ile iki şirketin finansal performansı ölçülerek şirketler arasında farklılık testi uygulanmıştır. Dikey analiz sonucunda kamu sektörü şirketinin yıllar itibarıyla uzun vadeli borçlarını erittiği ve kârını ciddi bir oranda arttırarak yatırıma dönüştürdüğü gözlemlenirken, özel sektör şirketinin de uzun vadeli borçlarını ödediği ve maddi duran varlıklarını satıp yatırıma dönüştürdüğü veya yenileme çalışmasına gittiği yine kârlılığını arttırdığı sonucuna varılmıştır. Çalışmada genel olarak iki şirketin de ihtiyatlı finansman politikaları izledikleri ortaya konulmuştur.

Konaklama sektörüne yönelik yapılan bir çalışmada Singh ve Schmidgall (2013), Amerikan konaklama şirketlerinin 2010-2011 yıllarındaki finansal performanslarının firma büyüklüklerine göre değiş̧ip değişmediğini araştırmışlardır. Çalışmada Amerika'da faaliyet gösteren 2091 konaklama şirketinin dikey analizi ve oran analizini gerçekleştirmiştir. Şirketler firma büyüklüğüne göre 0-500 bin dolar, 500 bin dolar-2 milyon dolar, 2-10 milyon dolar, 10-50 milyon dolar, 50-100 milyon dolar, 100-250 milyon dolar olarak sınıflandırılmıştır. Çalışmada yapılan analizin sonucuna göre altı grubun da genel olarak duran varlık ağılıklı oldukları ve bu varlıkları uzun vadeli borçlarla karşıladıkları görülmektedir. Ancak firma büyüklüğü 0-500 bin dolar arasında olan şirketlerin duran varlıklarının ve uzun vadeli borçlarının diğer firmalara göre çok az kaldığı ve daha çok dönen varlık ağırlıklı oldukları görülmektedir. Gelir tablolarına bakıldığında ise şirketlerin genel olarak çok yüksek miktarda faaliyet giderinin olduğu görülmektedir. Vergi öncesi kâr kalemine bakıldığında ise firma büyüklüğü 50-250 milyon dolar arasındaki şirketlerin zararda oldukları ortaya çıkmıştır.

Yahya ve diğ. (2013), Pakistan'da faaliyet gösteren iki gida işletmesinin 2008-2011 yıllarındaki finansal performanslarını inceledikleri çalışmada dikey analiz, karşılaştırmalı (yatay) analiz, DuPont analizi ve oran analizi yöntemlerini kullanmışlardır. Çalışmada iki şirketinde borç düzeylerinin çok düşük olduğu ve stoklarının yüksek düzeyde olduğu, diğer taraftan satışlarının maliyetinin çok yüksek olduğu ve vergi öncesi kârlarının ortalama \%12 civarında olduğu ortaya çıkmıştır.

Omağ (2013), Türkiye'de faaliyet gösteren büyük ölçekli bir gıda işletmesinin 20112012 yıllarındaki tablolarının dikey analizini gerçekleştirerek işletmenin finansal tablolarındaki değişimlerin nedenlerini incelemiştir. Çalışmada incelenen işletmenin duran varlıklarının \%60 civarında olduğu ve \%40 civarında dönen varlıklarının olduğu ortaya çıkmıştır. Dönen varlıkların önemli bir kısmının ticari alacaklar ve stoklardan oluştuğu görülmektedir. İşletmenin özkaynaklarının \%70 civarında olduğu ve uzun vadeli borçlarının yok denecek kadar az olduğu ortaya çıkmıştır. Gelir tablosuna bakıldığında ise satışların maliyetinin \%80’lerde gerçekleşmesi ve genel yönetim giderleri ile pazarlama, satış ve 
dağıtım giderlerinin yüksek gerçekleşmesi ile kârın \%1'lerde gerçekleşmesine neden olduğu ortaya konulmuştur.

Demir ve Çelik (2015), 882 ihracatçı şirketin 2009-2011 yıllarına ait finansal analizlerini ortaya koymuşlardır. Çalışmada şirketlere ait oranlar TCMB tarafindan hazırlanan sektörel finansal oranlar ile karşılaştırılmıştır. Ayrıca çalışmada şirketler, faaliyet gösterilen sektörlere göre gruplandırılarak sektörel farklılıklar ortaya konulması amaçlanmıştır. Çalışmada dikey analiz yöntemi ile yapılan analizin sonuçlarına bakıldığında, şirketlerin dönen varlık oranı ortalamalarının 2009-2011 yılları arasında sirasıyla \%68,54; \%70,08 ve \%71,51 olduğu ve bunun üzerine ihracat şirketlerinin dönen varlık ağırlıklı oldukları görülmektedir. Bu şirketlerin dönen varlıklarının büyük kısmının ise ticari alacaklar ve stoklardan oluştuğu görülmektedir. Şirketlerin pasif yapıları incelendiğinde kısa vadeli yabancı kaynakların ağırlıklı olduğu ve 2009-2011 yılları arasında sırasıyla kısa vadeli yabancı kaynak oranının ortalama \%50,43; \%52,78 ve \%56,67 olarak gerçekleştiği görülmektedir. Buna göre çalışmada, ihracat şirketlerinin kısa vadeli borç ve alacaklarının kriz sonrasında artış gösterdiği ve şirketlerin finansal sıkıntı yaşadıkları sonucuna varılmıştır.

Göçer (2015), Türkiye'deki bir belediyenin 2008-2012 yılları arasındaki bilanço ve bütçe sonuçları tablolarının yatay ve dikey analiz yöntemlerini kullanarak finansal analizini gerçekleştirmiştir. Analiz neticesinde incelenen belediyenin varlıklarının \%90'dan fazlasının duran varlıklardan oluştuğu ve bunun özkaynaklarla finanse edildiği ortaya konulmuştur. Bütçe tablolarına bakıldığında ise bütçe gelirlerinin büyük bir kısmının vergi gelirleri, sermaye gelirleri ve diğer gelirlerden oluştuğu görülürken bütçe giderlerinin büyük bir kısmının ise mal ve hizmet alım giderleri ile sermaye giderlerinden oluştuğu ortaya çıkmıştır.

Şen, Zengin ve Yusubov (2015), bir örnek otel işletmesinin finansal tablolarını finansal analiz tekniklerini kullanarak analiz etmek amacıyla bir çalışma gerçekleştirmişlerdir. Çalışma kapsamında Borsa İstanbul turizm endeksinde yer alan bir konaklama şirketinin 2011-2013 yıllarına ait finansal tabloları analiz edilmiştir. Çalışmada finansal analiz tekniklerinden trend analizi, karşılaştırmalı tablolar analizi, dikey analiz ve oran analizi uygulanmıştır. Çalışmanın dikey analiz bulgularına göre 2013 yılındaki finansal verileri incelenen konaklama işletmesinin, aktifinin yaklaşık \%77 oranında duran varlıktan oluştuğu ve bununda büyük oranda maddi duran varlıklar kaleminden kaynaklandığ görülmektedir. Çalışmada şirketin pasif kısmında ise yaklaşık \%43 oranında uzun vadeli yabancı kaynağın olduğu, bunun yanında yaklaşık \%37 oranında kısa vadeli yabancı kaynağın olduğu görülmektedir. Çalışmada ayrıca incelenen konaklama şirketinin gelir tablosuna bakıldığında satış gelirlerinin yaklaşı $\% 64$ 'ünün satış maliyetine sahip olduğu ve bunun yanında şirketin satışlarının yaklaşık \%68'i kadar finansman gideri ile karşılaşması sonucu büyük zarar ettiği ortaya çıkmıştır.

Sonğur ve diğ. (2016), Türkiye Kamu Hastaneleri Kurumu'na bağlı kamu hastane birlikleri kapsamındaki Sağlık Bakanlığı hastanelerinin birlik kapsamına geçiş öncesi (2008- 
2012 dönemleri) ve sonrası (2013-2015 dönemleri) finansal tablolar analizleri yöntemiyle genel finansal performanslarını ortaya koymak amacıyla bir çalışma gerçekleştirmişlerdir. Çalışmada oran analizi, dikey analiz ve trend analizi yöntemleri uygulanmıştır. Çalışmanın dikey analiz bulguları incelendiğinde kamu hastane birlikleri hastanelerinin aktiflerinin $\% 75$ ile \%79 arasında dönen varlıklardan oluştuğu ve dönen varlıklar içindeki en yüksek payın \%45-\%65 oranı ile ticari alacaklar kalemine ait olduğu görülmektedir. Yine çalışmada kamu hastane birlikleri hastanelerinin pasif yapıları incelendiğinde özellikle 2012 yılına kadar kısa vadeli yabancı kaynak ile özkaynakların birbirine yakın oranlarda olduğu ancak 2012 yılından sonra kısa vadeli yabancı kaynakların ciddi bir artış göstererek \%140 civarına ulaştığı ve özkaynakların ise ciddi bir azalışla negatif değerlere gerilediği görülmektedir. 2012 yılından sonra şirketlerin negatif özkaynak değeri almasının dönem net zararı kaleminin yükselmesinden kaynaklandığ 1 açıklanmıştır.

Turizm sektörüne yönelik olarak finansal analiz yöntemlerinin kullanıldığı sınırlı sayıda çalışma vardır. Kim ve Ayoun (2005), çalışmalarında hizmet sektöründeki konaklama, restoran, havayolu ve eğlence merkezleri olmak üzere dört faklı grubu oran analizi yöntemiyle karşılaştırmışlardır. Kim ve diğerleri (2002), otelcilik endüstrisinde, gayrimenkul yatırım ortaklığı performansının ölçümünü finansal oranlar yardımıyla ölçmüşlerdir. Kahiloğulları ve Karadeniz (2015), hisseleri Avrupa ve Türkiye borsalarında işlem gören konaklama şirketlerinin finansman yapılarını oran analizi yöntemiyle belirlemişlerdir. Ecer ve Günay (2014), Türkiye'de BİST'te işlem gören 9 turizm şirketinin 2008-2012 yıllarına ait finansal performanslarını oran analizi yöntemiyle ölçmüşlerdir.

\section{Yöntem}

Dikey analiz yöntemi, finansal tabloları oluşturan kalemlerin değerinin önemini ortaya koyması açısından yararlıdır. Dikey analiz yönteminde finansal tablolarda yer alan her kalemin ait olduğu grup içerisindeki yüzdesi, grup toplamına veya genel toplama göre gösterilir (Ceylan \& Korkmaz, 2012: 75). Dikey analizde işletmelerin tek bir dönemine ilişkin finansal tabloları esas alındığından bu yöntemin statik bir analiz yöntemi olduğu kabul edilmektedir (Karapınar \& Zaif, 2013: 71).

Dikey analiz bir işletmenin kaynaklarının dağılımını göstermesi açısından önemlidir. $\mathrm{Bu}$ analiz ile işletmenin varlıklarının ne kadarının dönen varlıklarda ne kadarının duran varlıklarda olduğu ve kaynaklarının ne kadarının özkaynaklardan ne kadarının yabancı kaynaklardan oluştuğu ortaya çıkarılabilir (Türko, 1999: 116). Dikey analiz ile gelir tablosunun da incelenerek, net kârın elde edilmesi için yapılan harcamaların dağılımını görmek mümkündür. Gelir tablosunun dikey analizinde her bir kalemin grup içindeki payı hesaplanabileceği gibi, tüm kalemlerin net satışlara oranlanmasıyla da işlemler yapılabilir. Her bir kalemin net satışlar içindeki payı hesaplanırken net satışlar toplamı 100 kabul edilir (Ceylan \& Korkmaz, 2012: 76).

Dikey analiz yönteminin diğer finansal analiz yöntemlerine kıyasla bazı avantajlarının olduğu bilinmektedir. Örneğin, dikey analiz yöntemiyle finansal tablolarda 
yer alan her bir kalemin toplam içindeki oranı açıç̧a ortaya konulabilmesi bu yöntemin bir avantajıdır. Buna karşın finansal tablolarda yer alan kalemlerdeki değişiklikler salt rakamsal olarak ifade edildiği zaman, aynı sektörde yer alan işletmeler arasında anlamlı karşılaştırmaların yapılması mümkün olmamaktadır. Ancak dikey analiz yöntemi ile finansal tablolardaki kalemlerin yüzdesel olarak ifade edilmesi ile aynı sektörde yer alan işletmeler arasında veya sektör ortalaması ile karşılaştırmaların yapılması mümkün hale gelmektedir (Aydın \& Başar \& Coşkun, 2010: 136).

Analizin uygulanmasinda ilk olarak, finansal tabloda ortak esasa indirgemede esas alınacak kalem belirlenir. Bu kalem, bilançoda genellikle varlıklar veya kaynaklar toplamı, gelir tablosunda ise satı̧ gelirleri (hasılat) kalemidir. Belirlenen kalemler 100 kabul edilir ve diğer kalemlerin buna göre oranı bulunur. Her bir finansal tablo kaleminin, baz alınan kaleme göre alacağı değer aşağıdaki formül yardımı ile hesaplanır (Karapınar \& Zaif, 2013: 72).

$$
\text { Dikey Yüzde }=\frac{\text { İlgili Kalem Verisi }}{\text { Grup Toplamı Alınan Kalem Verisi }} \times 100
$$

Formülde belirtildiği şekilde hesaplanan yüzdelik tutarlar, işletmenin diğer dönemleriyle, diğer işletmelerle veya sektör ortalaması ile karşılaştırılarak yorumlanabilmektedir. (Karapınar \& Zaif, 2013: 75).

Bu çalışmanın temel amacı, hisseleri Borsa İstanbul'da işlem gören turizm şirketlerinin dikey analiz yöntemi ile finansal durumlarını ortaya koymak ve turizm sektörü ile bir karşılaştırma yapmaktır. Bu amaç doğrultusunda hisseleri Borsa İstanbul'da işlem gören turizm şirketlerinin ve Türkiye Cumhuriyet Merkez Bankası'nın yayınladığı sektör bilançolarından konaklama ve yiyecek hizmeti faaliyetleri alt sektörünün 2014 y1lına ait bilanço ve gelir tablolarında yer alan kalemlerde meydana gelen oransal değişimler hesaplanarak açıklanmaya çalışılmıştır. Türkiye'de faaliyette bulunan 13 halka açık turizm şirketinden 3'ünün finansal verilerinin analize uygun olmadığ görülmüş ve toplamda 10 halka açık turizm şirketinin 2014 yılına ait finansal analizi dikey analiz yöntemine göre gerçekleştirilmiştir. Analize dahil edilen halka açık turizm şirketlerinin (Altınyunus Çeşme Turistik Tesisler A.Ş. - AYCES, Avrasya Petrol ve Turistik Tesisler Yatırımlar A.Ş. AVTUR, Kuştur Kuşadası Turizm Endüstrisi A.Ş. - KSTUR, Marmaris Altınyunus Turistik Tesisler A.Ş. - MAALT, Merit Turizm Yatırım ve İşletme A.Ş. - MERIT, Metemtur Otelcilik ve Turizm İşletmeleri A.Ş. - METUR, Net Turizm Ticaret ve Sanayi A.Ş. - NTUR, Tek-Art İnşaat Ticaret Turizm Sanayi ve Yatırımlar A.Ş. - TEKTU, Ulaşlar Turizm Yatııımları ve Dayanıklı Tüketim Malları Ticaret Pazarlama A.Ş. - ULAS, Utopya Turizm İnşaat İşletmecilik Ticaret A.Ş. ve Bağlı Ortaklıkları - UTPYA) verilerine Kamuyu Aydınlatma Platformu internet adresinden (www.kap.gov.tr) erişilmiştir. Ayrıca konaklama ve yiyecek hizmeti faaliyetinde bulunan 493 işletmenin TCMB'ye gönüllülük esasına göre göndermiş oldukları bilanço ve gelir tablolarından oluşturulmuş olan konaklama ve yiyecek hizmeti faaliyetleri alt sektörünün 2014 yılına ait finansal durumu dikey analiz yöntemi ile yapılmıştır. Konaklama ve yiyecek hizmeti faaliyetleri alt sektörünün finansal tabloları ise 
Türkiye Cumhuriyet Merkez Bankası'nın internet adresinden (www.tcmb.gov.tr) alınmıştır. Böylece Borsa İstanbul turizm şirketlerinin finansal tablolarındaki kalemler sektör ile karşılaştırılarak aradaki farklılıklar yorumlanmaya çalışılmıştır.

\section{Bulgular}

Borsa İstanbul turizm șirketlerinin ve konaklama ve yiyecek hizmeti faaliyetleri alt sektörünün 2014 yılına ait finansal tablolarının dikey yüzde yöntemiyle gerçekleştirilen finansal analize ilişkin sonuçlar bu bölümde yer almaktadır. Analiz sonuçları yorumlanırken finansal tablolardaki ana kalemlerin hangi alt kalemlerden oluştuğu ve toplam içindeki payları incelenerek sektör ile karşıllaştırılmıştır. Borsa İstanbul turizm şirketleri ve konaklama ve yiyecek hizmeti faaliyetleri alt sektörüne ait 2014 y1l finansal durum tablolarının aktif kalemlerinin dikey analizi Tablo 1'de yer almaktadır.

\section{Tablo: 1}

\section{Analize Dahil Edilen Şirketlerin Finansal Durum Tablolarındaki Aktif Kalemlerin Yüzde Cinsinden Değerleri}

\begin{tabular}{|c|c|c|c|c|c|c|c|c|c|c|c|}
\hline ŞIRKETLER & AYCES & AVTUR & KSTUR & MAALT & MERIT & METUR & NTTUR & TEKTU & ULAS & UTPYA & SEKTÖR \\
\hline KALEMLER & 2014 & 2014 & 2014 & 2014 & 2014 & 2014 & 2014 & 2014 & 2014 & 2014 & 2014 \\
\hline Dönen Varlıklar & $2,3 \%$ & $36,5 \%$ & $32,2 \%$ & $28,7 \%$ & $17,4 \%$ & $71,3 \%$ & $21,2 \%$ & $25,0 \%$ & $27,9 \%$ & $11,5 \%$ & $27,6 \%$ \\
\hline Nakit ve Nakit Benzerleri & $0,9 \%$ & $0,1 \%$ & $18,3 \%$ & $28,5 \%$ & $0,0 \%$ & $0,9 \%$ & $17,7 \%$ & $0,9 \%$ & $24,5 \%$ & $0,3 \%$ & $8,6 \%$ \\
\hline Ticari Alacaklar & $0,6 \%$ & $0,7 \%$ & $12,7 \%$ & $0,2 \%$ & $9,9 \%$ & $0,1 \%$ & $0,4 \%$ & $6,7 \%$ & $2,1 \%$ & $7,6 \%$ & $6,8 \%$ \\
\hline Diğer Alacaklar & $0,1 \%$ & $34,2 \%$ & $0,0 \%$ & $0,0 \%$ & $0,0 \%$ & $0,3 \%$ & $0,0 \%$ & $16,3 \%$ & $0,1 \%$ & $2,0 \%$ & $4,2 \%$ \\
\hline Stoklar & $0,3 \%$ & $0,0 \%$ & $0,0 \%$ & $0,0 \%$ & $0,0 \%$ & $52,8 \%$ & $0,2 \%$ & $0,0 \%$ & $0,5 \%$ & $0,6 \%$ & $4,7 \%$ \\
\hline Diğer Dönen Varlıklar & $0,5 \%$ & $1,5 \%$ & $1,2 \%$ & $0,0 \%$ & $7,5 \%$ & $17,2 \%$ & $3,0 \%$ & $1,0 \%$ & $0,7 \%$ & $1,0 \%$ & $3,3 \%$ \\
\hline Duran Varlıklar & $97,7 \%$ & $63,5 \%$ & $67,6 \%$ & $71,2 \%$ & $82,6 \%$ & $28,3 \%$ & $78,8 \%$ & $75,0 \%$ & $72,1 \%$ & $88,5 \%$ & $72,4 \%$ \\
\hline Finansal Yatırımlar & $1,1 \%$ & $0,0 \%$ & $0,0 \%$ & $0,0 \%$ & $81,9 \%$ & $0,0 \%$ & $1,1 \%$ & $4,1 \%$ & $0,0 \%$ & $3,1 \%$ & $8,0 \%$ \\
\hline Özkaynak Yön. Değ. Yatırımlar & $0,0 \%$ & $0,0 \%$ & $0,0 \%$ & $0,0 \%$ & $0,0 \%$ & $0,0 \%$ & $56,4 \%$ & $0,0 \%$ & $0,0 \%$ & $0,0 \%$ & $0,0 \%$ \\
\hline Yat. Amaçlı Gayrimenkuller & $0,0 \%$ & $9,8 \%$ & $0,0 \%$ & $43,2 \%$ & $0,0 \%$ & $0,0 \%$ & $7,0 \%$ & $23,3 \%$ & $2,9 \%$ & $1,9 \%$ & $0,0 \%$ \\
\hline Maddi Duran Varlıklar & $96,5 \%$ & $48,8 \%$ & $67,6 \%$ & $28,0 \%$ & $0,0 \%$ & $12,2 \%$ & $13,4 \%$ & $47,6 \%$ & $69,1 \%$ & $82,2 \%$ & $53,2 \%$ \\
\hline Mad. Olmayan Duran Var. & $0,1 \%$ & $4,9 \%$ & $0,0 \%$ & $0,0 \%$ & $0,2 \%$ & $0,0 \%$ & $0,0 \%$ & $0,0 \%$ & $0,1 \%$ & $0,4 \%$ & $7,9 \%$ \\
\hline Ertelenmiş Vergi Varlığ1 & $0,0 \%$ & $0,0 \%$ & $0,0 \%$ & $0,0 \%$ & $0,5 \%$ & $16,1 \%$ & $0,9 \%$ & $0,0 \%$ & $0,0 \%$ & $0,0 \%$ & $0,0 \%$ \\
\hline Diğer Duran Varlıklar & $0,0 \%$ & $0,0 \%$ & $0,0 \%$ & $0,0 \%$ & $0,0 \%$ & $0,0 \%$ & $0,0 \%$ & $0,0 \%$ & $0,0 \%$ & $1,0 \%$ & $3,3 \%$ \\
\hline TOPLAM VARLIKLAR & $100 \%$ & $100 \%$ & $100 \%$ & $100 \%$ & $100 \%$ & $100 \%$ & $100 \%$ & $100 \%$ & $100 \%$ & $100 \%$ & $100 \%$ \\
\hline
\end{tabular}

Tablo 1'e göre Metemtur Otelcilik ve Turizm İşletmeleri A.Ş. (METUR) dışında bütün şirketlerin ve sektörün duran varlık ağırlıklı bir yapıda olduğu görülmektedir. Şirketlerin dönen varlıkları genel olarak \%25-30 arasında bir paya sahip olduğu ve en yüksek dönen varlık payına sahip şirketin METUR olduğu söylenebilir. METUR'un dönen varlıkları incelendiğinde en yüksek paya sahip dönen varlık kaleminin stoklar olduğu ve sektöre göre çok büyük farklılık gösterdiği görülmektedir. Söz konusu farklılığın nedeni araştırıldığında bu şirketin yapmış olduğı inşaat sözleşmelerinin yerine getirilmesi ile yapılan tatil köyünden 26 adet yazlık villanın satışa konulduğu ortaya çıkmışır. Diğer şirketlerin dönen varlıkları incelendiğinde genel olarak nakit ve nakit benzeri kalemi ile 
ticari alacaklar kaleminin dönen varlıkları oluşturduğu ve bunun sektörün dönen varlıkları ile benzerlik gösterdiği söylenebilir. Duran varlıklara bakıldığında ise şirketlerin finansal durum tablolarındaki varlıklar bölümünde en yüksek duran varlık payına sahip şirketin \%97,7 ile Altınyunus Çeşme Turistik Tesisler A.Ş. (AYCES) olduğu görülmektedir. Bu şirketin duran varlıkları incelendiğinde maddi duran varlıklar kaleminin çok yüksek bir paya sahip olduğu görülmekedir. Utopya Turizm İnşaat İşletmecilik Ticaret A.Ş. (UTPYA), Merit Turizm Yatırım ve İşletme A.Ş. (MERIT) ve Net Turizm Ticaret ve Sanayi A.Ş. (NTTUR) duran varlık oranları çok yüksek olan diğer işletmelerdir. Bu şirketlerden UTPYA'nın duran varlıkların önemli payını maddi duran varlıklar oluştururken MERIT'te finansal yatırımlar, NTTUR'da ise özkaynak yöntemiyle değerlenen yatırımlar, duran varlıkları büyük ölçüde oluşturan kalemlerdir. Diğer şirketlerin de METUR haricinde genel anlamda \%65-75 civarında duran varlık oranının olduğu ve bunların maddi duran varlıklardan oluştuğu görülmektedir. Sektörde ise duran varlıkların önemli bir payı yine maddi duran varlıklardan oluşsa da finansal yatırımlar ve maddi olmayan duran varlıkların da belli bir düzeyde paylarının olduğu görülmektedir. $\mathrm{Bu}$ bağlamda genel olarak Borsa İstanbul turizm şirketlerinin duran varlıklarının toplam varlıklar içerisindeki payının sektörle benzerlik gösterdiği ancak maddi duran varlıkların sektöre kıyasla daha fazla olduğu söylenebilir. Borsa İstanbul turizm şirketleri ve konaklama ve yiyecek hizmeti faaliyetleri alt sektörüne ait 2014 yılı finansal durum tablolarının pasif kalemlerinin dikey analizi Tablo 2'de yer almaktadir.

Tablo: 2

\section{Analize Dahil Edilen Şirketlerin Finansal Durum Tablolarındaki Pasif Kalemlerin Yüzde Cinsinden Değerleri}

\begin{tabular}{|c|c|c|c|c|c|c|c|c|c|c|c|}
\hline ŞİRKETLER & AYCES & AVTUR & KSTUR & MAALT & MERIT & METUR & NTTUR & TEKTU & ULAS & UTPYA & SEKTÖR \\
\hline KALEMLER & 2014 & 2014 & 2014 & 2014 & 2014 & 2014 & 2014 & 2014 & 2014 & 2014 & 2014 \\
\hline Kısa Vad. Yükümlülükler & $9,2 \%$ & $3,4 \%$ & $15,9 \%$ & $1,6 \%$ & $9,5 \%$ & $28,3 \%$ & $6,6 \%$ & $17,6 \%$ & $27,6 \%$ & $30,7 \%$ & $24,2 \%$ \\
\hline Finansal Borçlar & $5,9 \%$ & $0,0 \%$ & $0,0 \%$ & $0,0 \%$ & $0,0 \%$ & $25,6 \%$ & $5,6 \%$ &, $2 \%$ & $25,1 \%$ & $1,8 \%$ & $5,8 \%$ \\
\hline Ticari Borçlar & $2,6 \%$ & $0,1 \%$ & $1,7 \%$ & $0,3 \%$ & $1,1 \%$ & $1,0 \%$ & $0,3 \%$ & $0,9 \%$ & $1,3 \%$ & $4,2 \%$ & $6,6 \%$ \\
\hline Diğer Borçlar & $0,3 \%$ & $1,9 \%$ & $1,2 \%$ & $0,2 \%$ & $1,6 \%$ & $1,3 \%$ & $0,3 \%$ & $0,1 \%$ & $0,5 \%$ & $6,2 \%$ & $5,7 \%$ \\
\hline Diğ. KısaVad. Yükümlülükler & $0,4 \%$ & $1,4 \%$ & $13,0 \%$ & $1,1 \%$ & $6,8 \%$ & $0,3 \%$ & $0,4 \%$ & $9,4 \%$ & $0,7 \%$ & $8,5 \%$ & $5,1 \%$ \\
\hline Uzun Vadeli Yükümlülükler & $8,1 \%$ & $4,8 \%$ & $0,1 \%$ & $0,5 \%$ & $0,7 \%$ & $100,7 \%$ & $4,4 \%$ & $2,7 \%$ & $27,5 \%$ & $20,0 \%$ & $45,1 \%$ \\
\hline Finansal Borçlar & $0,0 \%$ & $0,1 \%$ & $0,0 \%$ & $0,0 \%$ & $0,0 \%$ & $100,5 \%$ & $3,8 \%$ & $0,0 \%$ & $25,6 \%$ & $17,6 \%$ & $42,5 \%$ \\
\hline Diğ. Uzun Vad. Yükümlü & $8,1 \%$ & $4,7 \%$ & $0.1 \%$ & $0,5 \%$ & $0,7 \%$ & $0,2 \%$ & $0,7 \%$ & $2,7 \%$ & $1,9 \%$ & $2,3 \%$ & $2,6 \%$ \\
\hline YÜKÜMLÜLÜKLER & $17,3 \%$ & $8,2 \%$ & $16,1 \%$ & $2,2 \%$ & $10,1 \%$ & $129,0 \%$ & $11,0 \%$ & $20,3 \%$ & $5,0 \%$ & $0,7 \%$ & $69,3 \%$ \\
\hline ÖZKAYNAKLAR & $82,7 \%$ & $91,8 \%$ & $83,9 \%$ & $97,8 \%$ & $89,9 \%$ & $-29,0 \%$ & $89,0 \%$ & $79,7 \%$ & $45,0 \%$ & $49,3 \%$ &, $7 \%$ \\
\hline Ödenmiș Sermaye & $21,0 \%$ & $89,0 \%$ & $27,0 \%$ & $113,0 \%$ & $130,0 \%$ & $82,0 \%$ & $29,0 \%$ & $71,0 \%$ & $39,0 \%$ & $18,0 \%$ & $26,0 \%$ \\
\hline Sermaye Yedekleri & $72,3 \%$ & $-0,1 \%$ & $-0,8 \%$ & $-2,4 \%$ & $-0,1 \%$ & $0,1 \%$ & $26,0 \%$ & $45,1 \%$ & $18,5 \%$ & $42,1 \%$ & $1,9 \%$ \\
\hline Kar Yedekleri & $0,1 \%$ & $0,0 \%$ & $7,8 \%$ & $0,0 \%$ & $0,0 \%$ & $0,2 \%$ & $0,1 \%$ & $0,4 \%$ & $0,1 \%$ & $0,1 \%$ & $2,3 \%$ \\
\hline Geçmiş Yıllar Kar/Zararlanı & $-9,9 \%$ & $-5,9 \%$ & $34,6 \%$ & $-18,2 \%$ & $-61,8 \%$ & $-87,2 \%$ & $19,8 \%$ & $-37,8 \%$ & $-9,7 \%$ & $-10,4 \%$ & $-1,5 \%$ \\
\hline Net Dönem Karı/Zararı & $-0,9 \%$ & $8,6 \%$ & $15,4 \%$ & $5,3 \%$ & $21,3 \%$ & $-24,1 \%$ & $14,5 \%$ & $1,0 \%$ & $-3,3 \%$ & $-0,5 \%$ & $2,0 \%$ \\
\hline TOPLAM KAYNAKLAR & $100 \%$ & $100 \%$ & $100 \%$ & $100 \%$ & $100 \%$ & $100 \%$ & $100 \%$ & $100 \%$ & $100 \%$ & $100 \%$ & $100 \%$ \\
\hline
\end{tabular}


Karadeniz, E. \& M. Beyazgül \& S. Dalak \& F. Günay (2017), “Türk Turizm Sektörünün Finansal Performansının Dikey Analiz Yöntemiyle İncelenmesi: BİST Turizm Şirketleri ve TCMB Sektör Bilançoları Üzerinde Bir Araştırma”, Sosyoekonomi, Vol. 25(32), 105-119.

Borsa İstanbul turizm şirketlerinin finansal durum tablolarındaki pasif kalemlerinin dağılımına bakıldı̆̆ında METUR dışında genel olarak özkaynak ağırlıklı bir yapida oldukları ve sektörün ise yabancı kaynak ağırlıklı bir yapıda olduğu görülmektedir. Kısa vadeli yükümlülükler kalemi incelendiğinde, UTPYA'nın \%30 olan kısa vadeli yükümlülük oranı ile diğer şirketlere kıyasla en yüksek kısa vadeli yükümlülük oranına sahip olan şirket olduğu ortaya çıkmıştır. METUR ve ULAS şirketlerinin de kısa vadeli yükümlülük oranlarının \%25-30 aralığında olduğu görülmektedir. Sektörün kısa vadeli borçları \%24 civarında olduğu görülmekte ve bu üç şirketin sektöre yakın bir oranda kısa vadeli yükümlülük oranına sahip olduğu ortaya çıkmaktadır. Bununla beraber bu üç şirketin kısa vadeli yükümlülüklerini oluşturan kalemlere bakıldığında finansal borçlar kaleminin önemli bir yer tuttuğu söylenebilir. Diğer yandan kısa vadeli yükümlülük oranının \%10-15 bandında seyrettiği KSTUR, MERIT ve TEKTU şirketlerinde ise diğer kısa vadeli yükümlülüklerin önemli bir yer tuttuğu görülmektedir.

Uzun vadeli yükümlülüklere bakıldığında Borsa İstanbul turizm şirketlerinden METUR'un \%100,7 uzun vadeli yükümlülüğünün olduğu göze çarpmaktadır. Bu şirketin finansal tabloları incelendiğinde uzun vadeli finansal borçlarının toplam kaynaklarını aştığı görülmektedir. Bu borcun detayı incelendiğinde şirketin uzun dönemli banka kredilerini ödeyememesi sebebiyle başka bir şirket ile uzun vadeli borç sözleşmesi imzaladığı ve bu borcun gayrimenkul satış vaadi ile ödeneceği belirtilmiştir. Aynı şirketin stoklarında görülen yüksek oran yine bu sözleşme gereğince yapılan gayrimenkullerin satışa konulmasından kaynaklandığı görülmektedir. Diğer şirketlere bakıldığında ULAS ve UTPYA şirketlerinin \%20-27 civarında uzun vadeli yükümlülüğe sahip oldukları bunun da yine finansal borçlardan oluştuğu görülmektedir. Sektörün uzun vadeli yükümlülüklerinin yüzdesi ise \%45 civarındadır. Buna göre Borsa İstanbul turizm şirketlerinin METUR hariç sektöre kıyasla çok daha az uzun vadeli boç kullandığı söylenebilir. METUR şirketinin ise tamamen uzun vadeli finansal borç kullanarak varlıklarını finanse etmesi, bu şirketin çok yüksek finansal risk üstlendiğini göstermektedir.

Borsa İstanbul turizm şirketleri arasında en yüksek özkaynak ağırlığına sahip olan şirketin \%97,8 ile Marmaris Altınyunus Turistik Tesisler A.Ş. (MAALT) olduğu ve bunun tamamının ödenmiş sermayeden oluştuğu görülmektedir. Bununla birlikte AVTUR ve MERIT şirketlerinin de \%80-90 bandında bir özkaynak yüzdesi olduğu ve bunların da ödenmiş sermayeden oluştuğu ortaya çıkmaktadır. Genel olarak bakıldığında Borsa İstanbul turizm şirketlerinin kaynaklarının çok büyük bir bölümünün özkaynaklardan oluştuğu söylenebilir. Sektör ortalamasının özkaynaklar oranı \%30 civarında olduğu ve bunun büyük bir bölümünün ödenmiş sermayeden oluştuğu görülmektedir. Buna göre Borsa İstanbul turizm şirketlerinin sektöre kıyasla çok daha fazla özkaynak ağırlıklı bir yapıda olduğu sonucu ortaya çıkmaktadır. Özkaynaklar incelendiğinde göze çarpan bir diğer husus da geçmiş yıllar kâr/zararları kalemidir. METUR şirketinin geçmiş yıllar zararlarının çok yüksek olması şirketin negatif öz sermayeye sahip olmasına yol açtı̆̆ görülmektedir. Bu şirketin yabancı kaynaklarının varlıklarından fazla olması ve uzun vadeli yabancı kaynak oranının payının çok yüksek olması şirketin çok yüksek miktarda faiz yükümlüğüne sahip 
olduğu ve finansal riskinin bu derece yüksek olmasının sermayesini erittiği söylenebilir. MERIT ve TEKTU geçmiş yıllar zararı yüksek olan diğer turizm şirketleridir.

Varlık ve kaynak bileşimlerinin uyumu açısından şirketlerin finansal durum tablolarına bakıldığında Borsa İstanbul turizm şirketlerinin kısa vadeli yükümlülüklerinin dönen varlıklarından daha düşük oranda gerçekleştiği görülmektedir. Şirketlerin kısa vadeli yükümlülüklerinin dönen varlıklarından daha düşük oranda gerçekleşmiş olması likidite sıkıntısı çekmemeleri bakımından olumlu olarak yorumlanabilir. Aynı zamanda dönen varlıkların duran varlıklara oranla çok düşük düzeyde olması şirketlerin yüksek satış hacmini yakalamalarını gerekli kılmaktadır. Yüksek satış hacmine ulaşamayan şirketlerin olumsuz sonuçlarla karşılaşabileceği söylenebilir. Diğer yandan genel olarak şirketlerin varlıklarının ağırlıklı olarak duran varlıklardan, kaynaklarının ise ağırlıklı olarak özkaynaklardan oluştuğu görülmektedir. Buna göre şirketlerin duran varlıklarını özkaynaklar ile finanse ettikleri söylenebilir. Şirketlerin özkaynaklarının yüksek düzeyde olması, vergi avantajından yeterince faydalanılmadığ ve bunun sermaye maliyetlerini arttırdığı sonucuna yol açacağ düşünülmektedir.

Borsa İstanbul turizm şirketleri ve konaklama ve yiyecek hizmeti faaliyetleri alt sektörüne ait 2014 y1lı kâr/zarar tablosu kalemlerinin dikey analizi Tablo 3'de yer almaktadır.

Tablo: 3

\section{Analize Dahil Edilen Şirketlerin Kâr/Zarar Tablosu Kalemlerinin Yüzde Cinsinden Değerleri}

\begin{tabular}{|c|c|c|c|c|c|c|c|c|c|c|c|}
\hline SIRKET & AYCES & AVTUR & KSTUR & MAALT & MERIT & METUR & NTTUR & TEKTU & ULAS & UTPYA & SEKTÖR \\
\hline KALEMLER & 2014 & 2014 & 2014 & 2014 & 2014 & 2014 & 2014 & 2014 & 2014 & 2014 & 2014 \\
\hline Hasslat & $100 \%$ & $100 \%$ & $100 \%$ & $100 \%$ & $100 \%$ & $0 \%$ & $100 \%$ & $100 \%$ & $100 \%$ & $100 \%$ & $100 \%$ \\
\hline Satıslarn Maliyeti & $-69,1 \%$ & $-186,3 \%$ & $-63,7 \%$ & $-42,3 \%$ & $-21,1 \%$ & $0.0 \%$ & $-80.6 \%$ & $-49,1 \%$ & $-72,8 \%$ & $-77.5 \%$ & $-73,4 \%$ \\
\hline BROT KAR (ZARAR) & $30,9 \%$ & $-86,3 \%$ & $36,3 \%$ & $57,7 \%$ & 78,996 & $0,0 \%$ & $19,4 \%$ & $50,9 \%$ & $27,2 \%$ & $22,5 \%$ & $26,6 \%$ \\
\hline Paz., Satıs ve Daḡt. Giderleri (-) & $-3,4 \%$ & $0,0 \%$ & $-1,0 \%$ & $-0,1 \%$ & $-15,3 \%$ & $0,0 \%$ & $-5,4 \%$ & $-4,0 \%$ & $-1,9 \%$ & $-5,7 \%$ & $-2,7 \%$ \\
\hline Genel Yönetim Giderleri (-) & $-27,0 \%$ & $-18,1 \%$ & $-4,5 \%$ & $-41,5 \%$ & $-21,3 \%$ & $0,0 \%$ & $-29,9 \%$ & $-24,0 \%$ & $-18,3 \%$ & $-4,7 \%$ & $-14,0 \%$ \\
\hline $\begin{array}{l}\text { Esas Faaliyetlerden Diğer } \\
\text { Gelirler }\end{array}$ & $0,6 \%$ & $134,3 \%$ & $10,9 \%$ & $20,2 \%$ & $5,7 \%$ & $0,0 \%$ & $6,8 \%$ & $33,2 \%$ & $6,6 \%$ & $3,6 \%$ & $14,5 \%$ \\
\hline $\begin{array}{l}\text { Esas Faaliyetlerden Diger } \\
\text { Giderler }\end{array}$ & $-2,2 \%$ & $-114,5 \%$ & $-5,3 \%$ & $-6,8 \%$ & $-0,4 \%$ & $0,0 \%$ & $-2,0 \%$ & $-51,4 \%$ & $-14,2 \%$ & $-4,2 \%$ & $-10,8 \%$ \\
\hline $\begin{array}{l}\text { ESAS FAALIYET KARI / } \\
\text { CZARARI }\end{array}$ & $-1,0 \%$ & $-84,6 \%$ & $36,4 \%$ & $29,5 \%$ & $47,7 \%$ & $0,0 \%$ & $-11,0 \%$ & $4,7 \%$ & $-0,6 \%$ & $11,5 \%$ & $13,6 \%$ \\
\hline $\begin{array}{l}\text { Yaturim Faaliyetlerinden } \\
\text { Gelirler }\end{array}$ & $0.1 \%$ & $332,1 \%$ & $0.3 \%$ & $0,2 \%$ & $0,0 \%$ & $0,0 \%$ & $486,8 \%$ & $19,2 \%$ & $0,0 \%$ & $15,8 \%$ & $3,0 \%$ \\
\hline $\begin{array}{l}\text { Yaturim Faaliyetlerinden } \\
\text { Giderler }(-)\end{array}$ & $0,0 \%$ & $-1,8 \%$ & $0,0 \%$ & $0,0 \%$ & $-0,6 \%$ & $0,0 \%$ & $-0,5 \%$ & $0,0 \%$ & $0,0 \%$ & $-31,0 \%$ & $-2,9 \%$ \\
\hline $\begin{array}{l}\text { Ozkaynak Yöntemiyle } \\
\text { Degerlenen Yaturmlarun } \\
\text { Kar/Zararlarndaki Paylar }\end{array}$ & $0,0 \%$ & $0,0 \%$ & $0,0 \%$ & $0,0 \%$ & $0,0 \%$ & $0,0 \%$ & $116,5 \%$ & $0,0 \%$ & $0,0 \%$ & $0,0 \%$ & \\
\hline $\begin{array}{l}\text { FINANSMAN GELFRI/ } \\
\text { (GIDERI ONCESI } \\
\text { FAALIYET KARI / } \\
\text { (ZARARI) }\end{array}$ & $-0,9 \%$ & $245,6 \%$ & $36,7 \%$ & $29,7 \%$ & $47,1 \%$ & $0,0 \%$ & $591,7 \%$ & $23,9 \%$ & $-0,6 \%$ & $-3,7 \%$ & $13,7 \%$ \\
\hline Finansal Gelirler & $2.5 \%$ & $0,0 \%$ & $5,1 \%$ & $26,8 \%$ & $0.0 \%$ & $0.0 \%$ & $27,6 \%$ & $7.2 \%$ & $1,7 \%$ & $0.0 \%$ & \\
\hline Finansal Giderler $(-)$ & $-5,0 \%$ & $0,0 \%$ & $-4,2 \%$ & $-2,5 \%$ & $-0,1 \%$ & $0.0 \%$ & $-47,6 \%$ & $-13,1 \%$ & $-22,8 \%$ & $0.0 \%$ & $-6,9 \%$ \\
\hline $\begin{array}{l}\text { SÖRDÖROLEN } \\
\text { FAALIYETLER VERGI } \\
\text { ONCESI KARI / (ZARARI) }\end{array}$ & $-3,4 \%$ & $245,6 \%$ & $37,6 \%$ & $54,0 \%$ & $47,0 \%$ & $0,0 \%$ & $571,8 \%$ & $18,0 \%$ & $-21,7 \%$ & $-3,7 \%$ & $6,8 \%$ \\
\hline $\begin{array}{l}\text { Sürdürülen Faaliyetler Vergi } \\
\text { Gelir/(Gideri }\end{array}$ & $-0,7 \%$ & 14,29 & $-6,3 \%$ & $0,0 \%$ & $-9,4 \%$ & $0,0 \%$ & $-10,3 \%$ & $-3,1 \%$ & $4,0 \%$ & $1,1 \%$ & $-1,4 \%$ \\
\hline DOONEM KARI/ZARARI & $-4,1 \%$ & $259,8 \%$ & $31,2 \%$ & $54,0 \%$ & $37,6 \%$ & $0,0 \%$ & $561,5 \%$ & $14,9 \%$ & $-17,7 \%$ & $-2,5 \%$ & $5,4 \%$ \\
\hline
\end{tabular}


Borsa İstanbul turizm şirketlerinn kâr/zarar tablolarına bakıldığında öncelikle brüt kâr marjı incelenmiştir. Buna göre en yüksek brüt kâr marjına sahip şirketin \% 78,9 ile MERIT olduğu daha sonra \%57,7 ile MAALT olduğu görülmektedir. $\mathrm{Bu}$ şirketlerin satışların maliyetinin diğer şirketlere göre düşük gerçekleştiği ortaya çıkmıştır. Diğer yandan satışların maliyetinin \%186 oranla en yüksek oranda gerçekleştiği firmanın AVTUR olduğu görülmektedir. Bu şirketin satış maliyetinin satış gelirlerinden daha yüksek olduğu ve bu nedenle \%86 oranında satış zararı oluştuğu görülmektedir. Sektörün satış maliyeti ise \% 73,4 olarak gerçekleşmiş ve sektör \%26,6 brüt kâr marjına sahip olmuştur. Buna göre brüt satış kârına göre Borsa İstanbul turizm şirketlerinden AYCES, KSTUR, NTTUR, ULAS ve UTPYA şirketlerinin sektöre yakın düzeyde brüt satış marjına sahip olduğu söylenebilir. METUR şirketinin ise 2014 yılı itibariyle satışının olmaması sebebiyle kâr/zarar tablosunun dikey analizi gerçekleştirilememiştir. Borsa İstanbul turizm şirketlerinin faaliyet giderleri incelendiğinde MERIT şirketinin \%15,3 ile en yüksek pazarlama, satış ve dağıtım giderlerine sahip olduğu, MAALT şirketinin \%41,5 ile en yüksek genel yönetim giderlerine sahip olduğu ve AVTUR'un çok yüksek düzeyde esas faaliyetlerden diğer gelir ve gider yüzdesine sahip olduğu görülmektedir. AVTUR'un esas faaliyetlerden diğer gelir ve giderlerinin yüzdelerinin çok yüksek oranda olduğu göze çarpmaktadır. Bu şirketin kâr/zarar tablosunun detaylarına bakıldığında adat gelirleri ile tahakkuk etmemiş giderler hesaplarının yüksek tutarlarda gerçekleştiği görülmüştür. Borsa İstanbul turizm şirketlerine genel olarak bakıldığında şirketlerin genel yönetim giderlerinin \%20 civarında olduğu ve bunun neticesinde esas faaliyet kârlarının düşük gerçekleşmesine sebebiyet verdiği söylenebilir. Sektörün kâr/zarar tablosuna bakıldığında da esas faaliyet kârını en fazla düşüren kalemin yine genel yönetim giderleri olduğu ortaya çıkmıştır.

Şirketlerin diğer giderleri ve gelirleri incelendiğinde AVTUR ve NTTUR şirketlerinin satışlarının 3-4 katı kadar yatırım faaliyetlerinden gelir elde ettikleri ve bu gelirin dönem kârlarının yüksek oranda gerçekleşmesini sağladığı ortaya çıkmıştır. Sektörde ise dönem kârını en çok düşüren giderin finansal giderler olduğu görülmektedir. Borsa İstanbul turizm şirketlerinin finansal gelir ve giderleri incelendiğinde ise MAALT'ın satışlarının \%26,8'i oranında finansal gelir elde ettiği ve dönem kârını ciddi miktarda arttırdığı söylenebilir. Diğer taraftan AYCES'in satışlarının \%5'i oranında ULAS'ın ise satışlarının \%22,8'i oranında finansal gidere maruz kaldığı ve zarar ettikleri görülmektedir. METUR'un satışlarının olmaması dolayısıyla dikey analizinin gerçekleştirilemediği ancak şirketin finansal durum tablosundan ve kâr/zarar tablosunun dipnotlarından anlaşıldığ üzere, şirketin çok yüksek oranda finansman giderine sahip olduğu ve zarar ettiği söylenebilir. Böylece oluşan dönem kârlarına bakıldığında en yüksek dönem kârına sahip şirketlerin satışlarının 5 katı kadar dönem kârı elde eden NTTUR ile satışlarının 2,5 katı kadar dönem kârı elde eden AVTUR olduğu ortaya çıkmıştır. AYCES, ULAS ve UTPYA şirketlerinin ise zarar ettikleri görülmektedir. Sektörün ise \%5,4 dönem kâr marjına sahip olduğu görülmektedir. Buna göre 2014 yılında Borsa İstanbul turizm şirketlerinin zarar eden üç şirket dışında sektörle kıyaslandığında çok daha yüksek oranda dönem kâr marjına sahip oldukları söylenebilir. 


\section{Sonuç}

Dikey analiz yöntemi, finansal tablo kalemlerinin yüzdesel olarak ifade edilerek işletmelerin hesaplarının dağılımını, bu hesapların yıllar itibariyle değişimini ve diğer işletmeler ile kıyaslanmasını mümkün kılması açısından önemli bir analiz tekniğidir. Dikey analiz yönteminin diğer yöntemlere kıyasla bazı üstünlükleri vardır. Bunlar; finansal tablolarda yer alan her bir kalemin toplam içindeki oranının açıkça ortaya konulabilmesi ve finansal tablolardaki kalemlerin yüzdesel olarak ifade edilerek aynı sektörde yer alan işletmelerle veya sektör ortalaması ile karşılaştırmaların yapılabilmesidir.

$\mathrm{Bu}$ çalışmanın amacı, hisseleri Borsa İstanbul'da işlem gören turizm şirketlerinin dikey analiz yöntemi ile finansal durumlarını ortaya koymak ve turizm sektörü ile bir karşılaştırma yapmaktır. Dikey analiz yöntemiyle işletmelerin çeşitli dönemlerindeki finansal durumlarını görmeleri ve sektördeki diğer işletmeler ile kıyaslama yapmalarına olanak sağlanarak gelecekle ilgili alınan kararlarda daha etkin olmaları sağlanabilmektedir. $\mathrm{Bu}$ açıdan dikey analizin turizm sektöründe yöneticilere önemli katkılar sağlayacağ düşünülmektedir. Bu bağlamda hisseleri Borsa İstanbul'da işlem gören 10 turizm şirketinin 2014 yılı finansal tabloları ve TCMB 2014 yılı sektör bilançolarından konaklama ve yiyecek hizmeti faaliyetleri alt sektörüne ait finansal tablolar dikey analiz yöntemiyle incelenmiş ve varlıkların, kaynakların ve kârların nasıl dağıldığı ortaya konularak bir karşılaştırma yapılmıştır.

Borsa İstanbul turizm şirketleri ve konaklama ve yiyecek hizmeti faaliyetleri alt sektörünün finansal tablolarından finansal durum tablolarının dikey analizi sonucunda Borsa İstanbul şirketlerinin varlıklarının dağılımı sektörle benzerlik gösterdiği ancak duran varlıkları oluşturan kalemler içinde maddi duran varlıkların payının sektöre göre daha yüksek bir oranda olduğu ortaya çıkmıştır. Kaynakların dağılımına bakıldığında ise Borsa İstanbul turizm şirketlerinin özkaynaklarının çok yüksek oranda olduğu sektörün ise daha çok yabancı kaynak ağırlıklı olduğu belirlenmiştir. Borsa İstanbul turizm şirketlerinden METUR, ULAS ve UTPYA'nın kısa vadeli yabancı kaynak oranı bakımından sektörle benzerlik gösterdiği diğer şirketlerin ise sektöre göre daha az kısa vadeli borçlandığı gözlenmiştir. Uzun vadeli yükümlülüklere bakıldığında ise sektörde METUR'un yüksek uzun vadeli yükümlülük düzeyine sahip olduğu ancak diğer şirketlerin çok az düzeyde uzun vadeli borçlandığı ortaya çıkmıştır. Sektörde ise \%45 civarında bir uzun vadeli yabancı kaynak oranı gözlenmiştir. Buna göre sektörün kaynak dağılımı daha dengeli bir görünümdeyken Borsa İstanbul turizm şirketlerinin kaynakları çok yüksek düzeyde özkaynaklardan oluşmaktadır. Bu bağlamda Borsa İstanbul turizm şirketlerinin duran varlıklarını özkaynaklarla finanse ettiği ve sektöre göre daha yüksek bir sermaye maliyetine sahip olduğu söylenebilir.

Borsa İstanbul turizm şirketleri ve konaklama ve yiyecek hizmeti faaliyetleri alt sektörünün finansal tablolarından kâr/zarar tablolarının dikey analizi sonucunda Borsa İstanbul turizm şirketlerinden AYCES, KSTUR, NTTUR, ULAS ve UTPYA'nın brüt kâr marjlarının sektörle benzer şekilde gerçekleştiği görülmektedir. Bu şirketlerin ortalama \%70 
civarında bir satış maliyetine sahip olduğu ve buna bağlı olarak \%30 civarında brüt kâr marjına sahip olduğu saptanmıştır. AVTUR'un ise satışlarının maliyetinin satış tutarını aştığı ve brüt satış zararı olduğu göze çarpmıştır. Genel olarak bakıldığında ise Borsa İstanbul şirketlerinin genel yönetim gideri oranı ortalama $\% 20$ civarında olup sektörle benzerlik göstermektedir. Şirketlerin dönem kârını en çok etkileyen kalemlere bakıldığında ise genel yönetim giderleri ile finansal giderler kalemleri göze çarpmaktadır. Bu bakımdan da Borsa İstanbul turizm şirketleri ile turizm sektörü birbirine benzerlik göstermektedir. Dönem kâr marjına bakıldığında ise Borsa İstanbul turizm şirketlerinden AYCES, ULAS ve UTPYA şirketlerinin zararda oldukları ancak bu üç şirket dışında genel olarak şirketlerin sektöre kıyasla çok daha yüksek kâr marjına sahip oldukları gözlemlenmiştir.

Konuyla ilgili alan yazın bağlamında Türkiye'de turizm sektöründe birden çok şirketin ve sektörün dikey analiz yöntemiyle incelendiği bir çalışmaya tarafımızca rastlanmamıştır. Bu kapsamda çalışma sonuçlarının şirket-sektör karşılaştırmasına imkânı sunması, Türk turizm sektörünün finansal tablolarındaki dağılımın açıkça ortaya konması ve eksikliklerinin tespit edilmesi açısından alan yazına katkı sağlayacağı düşünülmektedir. Çalışma sonucunda halka açık turizm şirketlerinin kar yaratmak konusunda giderlerini kontrol altında tutmaları, daha düşük maliyetli finansman kaynağı olan kısa ve uzun vadeli borç kullanım oranlarını arttırmaları yönünde adımlar atmaları önerilebilir. Bununla birlikte aktif ve pasif dengesini sağlamaları açısından daha fazla kısa vadeli borca yer vermeleri tavsiye edilmektedir. Çalışma sınırlı sayıdaki turizm şirketini kapsamaktadır. Daha çok sayıdaki şirketin analize dâhil edilmesiyle daha genelleştirilebilir sonuçlara ulaşılabilir. Ayrıca çalışmada halka açık turizm şirketleri ile Türkiye'deki turizm sektörü karşılaştırılmıştır. Ancak hem halka açık Türk turizm şirketleri hem de Türkiye'nin genel turizm sektörünün farklı ülkelerin turizm sektörleri ile karşılaştırmalarının yapılmasının önemli olacağı düşünülmektedir.

\section{Kaynaklar}

Aydın, N. \& M. Başar \& N. Coşkun (2010), Finansal Yönetim, Ankara: Detay Yayıncılık.

Bardia S.C. (2012), "Predicting Financial Distress and Evaluating Long-Term Solvency: An Empirical Study", The IUP Journal of Accounting Research and Audit Practices, 6(1), 47-61.

Ceylan, A. \& T. Korkmaz (2012), Işsletmelerde Finansal Yönetim, Bursa: Ekin Yayınevi.

Demir, V. \& I. Çelik (2015), “Türk İhracatçılarının Mali Tablo Analizleri: Kriz Sonrası Döneme İlişkin Sektörel Karşılaştırma”, Muhasebe ve Denetime Bakış, 15(46), 53-80.

Ecer, F. \& F. Günay (2014), “Borsa İstanbul'da İşlem Gören Turizm Şirketlerinin Finansal Performanslarının Gri İlişkisel Analiz Yöntemiyle Ölçülmesi”, 25(1), 35-48.

Göçer, K. (2015), "Mali Tablolar Analizi: Pendik Belediyesi Örneği”, Bilgi Ekonomisi ve Yönetimi Dergisi, 5(1), 139-161.

Gürkan, D. (2009), "Basın İşletmelerinin Finansman Sorunları ve Bir Finansal Analiz Uygulaması", Iletişim Kuram ve Araştırma Dergisi, 29, 23-52. 
Kahiloğulları, S. \& E. Karadeniz (2015), "Halka Açık Konaklama Şirketlerinin Finansal Yapılarının Analizi: Uluslararası Bir Karşılaştırma", Çankırı Karatekin Üniversitesi IIIBF Dergisi, 2, 531-548.

Kamuyu Aydınlatma Platformu, <http://kap.gov.tr/sirketler/islem-goren-sirketler/sektorler.aspx>, 11 Ocak 2016.

Karapınar, A. \& F. Zaif Ayıkoğlu (2013), Finansal Analiz: Uluslararası Finansal Raporlama Standartları Ile Uyumlu, Ankara: Gazi Kitabevi.

Kim, H. \& A.S. Matilla \& Z. Gu (2002), "Performance of Hotel Real Estate Investment Trusts: A Comparative Analysis of Jensen Indexes", International Journal of Hospitality Management, 85-9.

Kim, W.G. \& B. Ayoun (2005), "Ratio Analysis for the Hospitality Industry: A Cross Sector Comparison of Financial Trends in the Lodging, Restaurant, Airline and Amusement Sectors", Journal of Hospitality Financial Management, 13, 1-34.

Omağ, A. (2014), "Yüzde Yöntemi ile Analiz ve Gıda Sektörüne Yönelik Bir Uygulama”, Finansal Araştırmalar ve Çalışmalar Dergisi, 6(11), 65-82.

Özyürek, H. \& E. Erdoğan (2011), "Finansal Kurumlarda Mali Analiz ve Bir Uygulama”, Ekonomi Bilimleri Dergisi, 3(2), 229-238.

Sevim, Ş. \& T. Bozdoğan \& M.A. Canbolat (2009), "Kredi Taleplerinin Değerlendirmesinde Bilgisayar Destekli Mali Analiz Sonuçlarının Puanlaması ve Bir Model Denemesi”, Uşak Üniversitesi Sosyal Bilimler Dergisi, 2(2), 83-101.

Singh, A.J. \& R.S. Schmidgall (2013), "Does Financial Performance Depend On Hotel Size? Analysis of the Financial Profile of the U.S.Lodging Industry", Hospitality Review, 30(2), 109-125.

Sonğur, C. \& A. Kar \& M. Top \& A. Gazi \& A. Babacan (2016), "Türkiye Kamu Hastane Birlikleri Hastanelerinin Finansal Performanslarının Değerlendirilmesi: Finansal Tablo Analizleri”, Sayıştay Dergisi, 100, 1-26.

Şen, L.M. \& B. Zengin \& F. Yusubov (2015), “Otel İşletmelerinde Finansal Analizlere İlişkin Bir Örnek Olay İncelemesi”, İşletme Bilimi Dergisi, 3(1), 64-85.

Türkiye Cumhuriyet Merkez Bankası (2015), "Sektör Bilançoları (2012-2014)", <http://www3.tcmb.gov.tr/sektor/2015/menu.php>, 05.02. 2016.

Türko, M.R. (1999), Finansal Yönetim, 1. Bask1, İstanbul: Alfa Yayınevi.

Yahya, F. \& S.A. Ali \& Z. Mir \& M. Yaqoob \& U.A. Khan (2013), "Significant Analysis for Financial Statements: An Empirical Study of National and Unilever Foods", Research Journal of Finance and Accounting, 4(1), 26-34. 
Karadeniz, E. \& M. Beyazgül \& S. Dalak \& F. Günay (2017), “Türk Turizm Sektörünün Finansal Performansının Dikey Analiz Yöntemiyle İncelenmesi: BİST Turizm Şirketleri ve TCMB Sektör Bilançoları Üzerinde Bir Araştırma”, Sosyoekonomi, Vol. 25(32), 105-119. 